\section{Interleukin-1 $\beta$ secretion in hippocampal sclerosis patients with mesial temporal lobe epilepsy}

\author{
Nihal Olgac Dundar,1 Berrin Aktekin,2 \\ Nilufer Cicek Ekinci,3 Duygu Sahinturk,3 \\ Ugur Yavuzer, 4 Olcay Yegin, 5 \\ Senay Haspolat 6 \\ 1Department of Pediatric Neurology, \\ Izmir Katip Celebi University, Izmir; \\ 2Department of Neurology, Yeditepe \\ University Hospital, Istanbul; ${ }^{3}$ Central \\ Research Laboratory, Akdeniz University, \\ Antalya; ${ }^{4}$ Department of Physiology, \\ Akdeniz University, Antalya; \\ 5Department of Pediatric Allergy and \\ Immunology, Akdeniz University, \\ Antalya; ${ }^{6}$ Department of Pediatric \\ Neurology, Akdeniz University, Antalya, \\ Turkey
}

\section{Abstract}

Mesial temporal lobe epilepsy with hippocampal sclerosis (MTLE-HS) is a common medically intractable epilepsy syndrome. Although pathogenesis of HS still remains highly controversial, genetics may play a role as a predisposing factor. Previous evidence in a Japanese population revealed that the homozygotes for allele $\mathrm{T}$ at position -511 of the interleukin (IL)-1 $\beta$ gene promoter region (IL$1 \beta-511 \mathrm{~T} / \mathrm{T})$ confers susceptibility to the development of HS. However, whether this polymorphism has an effect on IL-1 $\beta$ levels in MTLEHS patients was not demonstrated. This study aimed to analyze the distribution of this particular polymorphism in a group of Turkish HS patients and correlate the polymorphism with IL-1 $\beta$ secretion from the lymphocytes, thus revealing a functional role for IL- $1 \beta$ in the etiopathogenesis of HS. A single base pair polymorphism at position -511 in the promoter region of the IL-1 $\beta$ gene was analyzed. The spontaneous and $1 \mathrm{ng} / \mathrm{mL}$ lipopolysaccharidestimulated production of IL-1 $\beta$ by peripheral blood mononuclear cells after 4 and $24 \mathrm{~h}$ of incubation were measured by ELISA method. The heterozygous type $(-511 \mathrm{C} / \mathrm{T})$ was the most common genotype. There was no difference in frequency of allele $-511 \mathrm{~T}$ between patients and controls. Analysis of IL-1 $\beta$ levels, genotype and allele distributions showed no significant difference among the groups $(\mathrm{P}>0.05)$. Nevertheless, it was seen that patients who carry a $\mathrm{T}$ allele at position -511 of the IL-1 $\beta$ gene had increased IL-1 $\beta$ levels. Tallele carriage may be important. Only IL-1 $\beta$ secretion from the lymphocytes has been assessed in this study. Considering the importance of IL-1 $\beta$ in the etiopathogenesis of HS, further studies are needed to evaluate locally produced IL-1 $\beta$ levels.

\section{Introduction}

Mesial temporal lobe epilepsy with hippocampal sclerosis (MTLE-HS) is the most common type of partial or localization-related seizure disorder in humans. The amygdala and hippocampus in the medial temporal lobe are important epileptogenic regions. Mesial temporal sclerosis (MTS) with prominent neuronal loss and gliosis in the hippocampus is the most common pathology in temporal lobe epilepsy (TLE).1,2 Although the pathogenesis and epileptogenesis of hippocampal sclerosis (HS) has been studied for years, the information available so far still does not fully explain the situation. Patients with MTLE-HS usually have a history of febrile seizures, status epilepticus, trauma or, in some cases, a mixture of all these symptoms. Recently, some studies have implicated inflammatory mechanisms that contribute or predispose to the occurrence of seizures in MTLE-HS.3-5

Cytokines such as interleukins (IL) are involved in inflammation, immune activation, cell differentiation and apoptosis. In seizures, activation of inflammatory cytokines has also been reported. There is increasing evidence to support the role of IL-1 in reducing seizure threshold and epileptogenesis in the pilocarpine status epilepticus model of epilepsy. ${ }^{6}$ IL-1 $\beta$ prolongs kainic acid induced seizures. ${ }^{7}$ Kanemoto et al. ${ }^{8}$ found a strong association between the homozygotes for allele $\mathrm{T}$ at position -511 of the IL-1 $\beta$ gene promoter region (IL-1 $\beta-511 \mathrm{~T} / \mathrm{T}$ ) and genetic predisposition to the development of HS in Japanese TLE patients. However, this finding has not been demonstrated in other ethnic groups. ${ }^{9-12}$ Kanemoto et al. ${ }^{13}$ stated that increased IL-1 $\beta$ 511 T-allele frequency proved to be a potent determinant of prolonged febrile seizure, thus a discrepancy in prolonged febrile seizure incidence could explain recent conflicting results.

Three polymorphisms within the IL-1 $\beta$ gene promoter region located at positions -1470, -511 and -31 basepairs from the transcription start site were found to be in strong linkage disequilibrium. Additionally, when analyzed in combination, these polymorphisms were demonstrated to alter the transcription of IL-1b gene. ${ }^{4,15}$ Interestingly, however, these two publications have conflicting results in terms of transcriptional activity of IL- $1 \beta$ promoter. While Chen et al. ${ }^{14}$ concluded that the IL-1 $\beta$ $511 \mathrm{~T}$ allele was associated with higher IL-1 $\beta$ promoter activity, Wen et al.15 demonstrated
Correspondence: Nihal Olgac Dundar, Department of Pediatric Neurology, Izmir Katip Celebi University, 35620, Izmir, Turkey.

Tel. +90.232.2444444-2755.

Fax: +90.232 .3860888 .

E-mail: nodundar@gmail.com

Key words: hippocampal sclerosis, interleukin$1 \beta$, polymorphism, temporal lobe epilepsy.

Contributions: NOD, BA, data collecting; NCE, DS, UY, data analyzing; NOD, UY, manuscript writing; OY, SH, manuscript reviewing and references search.

Conference presentation: part of this paper was presented at the 9th EPNS Congress, European Journal of Paediatric Neurology; Program and Abstract Book, p:37, May 11-14, 2011, Cavtat, Croatia.

Conflict of interests: the authors declare no potential conflict of interests.

Funding: the work was supported by Akdeniz University Scientific Committee (Project Number: 2009.04.0103.005).

Received for publication: 9 January 2013.

Accepted for publication: 8 April 2013.

This work is licensed under a Creative Commons Attribution NonCommercial 3.0 License (CC BYNC 3.0).

(C) Copyright N.O. Dundar et al., 2013

Licensee PAGEPress, Italy

Neurology International 2013; 5:e17

doi:10.4081/ni.2013.e17

that haplotype combinations carrying $-511 \mathrm{C}$ allele cause higher levels of secretion of IL-1 $\beta$ from the lipopolysaccharide (LPS)-stimulated lymphocytes. In both of these studies, promoter activity was assessed using constructs harboring different combinations of the abovementioned polymorhisms. Therefore, we intended to analyze the effect of $-511 \mathrm{C} / \mathrm{T}$ polymorphism on IL-I $\beta$ secretion from LPSinduced lymphocytes in an attempt to reveal the possible role of this particular polymorhism in the etiopathogenesis of MTLE-HS.

\section{Materials and Methods}

\section{Subjects}

Thirty patients with MTLE-HS admitted to the Akdeniz University Hospital Neurology Department, Turkey, were enrolled in this study. A control group of 32 healthy volunteers with matching age, gender ratio and ethnic origins was also included. Diagnosis of MTLE- 
HS was based on clinical history, electroencephalography, magnetic resonance imaging, and, in some patients, on histopathological findings after the selective amgydalahippocampectomy and anterior temporal lobectomy. The control subjects had no history of seizures or neurological disorders and no central nervous system or other infections at the time of blood sample collection. Written informed consent was obtained from the patient and control groups. The study was approved by the Ethics Committee of Akdeniz University Medical School Hospital. Clinical characteristics of the patient group are shown in Table 1.

\section{Genotyping using polymerase chain reaction-restriction fragment length polymorphism}

Peripheral venous blood samples $(3 \mathrm{~mL})$ were collected from each subject into Vacutainer tubes containing EDTA. DNA was extracted from blood samples using the robotic system MagNaPure (ROCHE) and the amount of DNA was measured by spectrophotometer. The -511 region of IL- $1 \beta$ gene has been genotyped with polymerase chain reaction-restriction fragment length polymorphism (PCR-RFLP) using $2 \mathrm{mg}$ of genomic DNA as template. By using the primers for $-511 \mathrm{C} / \mathrm{T}$ polymorphism described below, a 304 bp of DNA region was amplified by PCR (total 35 cycles, each cycle $30 \mathrm{~s}$ at $95^{\circ} \mathrm{C}, 45 \mathrm{~s}$ at $50^{\circ} \mathrm{C}$, and $45 \mathrm{~s}$ at $72^{\circ} \mathrm{C}$ ). The PCR products were purified by phenol/chloroform extraction and ethanol precipitation. Each PCR product was then cleaved by Ava I enzyme and the digested PCR products were subjected to agarose gel electrophoresis. The gels were stained with ethidium bromide and the DNA fragments were visualized by an UV transluminator. PCR products acquired from those with a CC genotype were cleaved into two fragments of 190 and 114 bp by Ava I enzyme, whereas the PCR products of people with TT genotype was not digested at all, yielding a product of $304 \mathrm{bp}$. Thus, samples that yielded all three fragments were designated heterozygotes.

Oligonucleotides used for PCR:

Forward Primer: 5'-TGGCATTGATCTGGTTCATC Reverse Primer: 5'-GTTTAGGAATCTTCCCACTT

\section{Measurement of IL1 $\beta$ levels using ELISA}

Peripheral blood of patients and healthy individuals was drawn into heparinized tubes, and lymphocytes were isolated with a density gradient method and pipetted into plates $(2 \times$ $10^{6}$ cells each well) and incubated for $24 \mathrm{~h}$ (5\% $\left.\mathrm{CO}_{2}, 37^{\circ} \mathrm{C}\right)$ in an RPMI 1640 culture medium including $10 \%$ FCS with $(0.5 \mathrm{ng} / \mathrm{mL})$ or without LPS. The cells were precipitated by centrifuge at $1600 \mathrm{rpm}$ for $10 \mathrm{~min}$ after 4 and $24 \mathrm{~h}$. The supernatants were transferred to another tube and stored at $-80^{\circ} \mathrm{C}$ until ELISA analyses. IL1 $\beta$ levels in cell culture supernatants were studied according to the manufacturer's protocol (eBioscience, cat. n. 88-7010).

\section{Statistical analysis}

All statistical analysis was carried out using Statistical Package for Social Sciences (SPSS) Windows version 15.0 (SPSS Inc., Chicago, IL, USA). Tests for differences in allelic and genotypic frequencies were performed using $\chi 2$ test and Fisher's exact test. Student's t-test was used to compare numeric variables within groups. Data were expressed as mean \pm standard deviation. $\mathrm{P}<0.05$ and an odds ratio with $95 \%$ confidence were considered to be statistically significant.

\section{Results}

Clinical features of MTLE-HS patients and controls are reported in Table 1. There was no difference in gender or age distribution between groups. The frequency of febrile seizures in patients was $76.6 \%$. IL-1 $\beta-511 \mathrm{C} / \mathrm{T}$ genotype and allele frequencies are summarized in Table 2. There was no significant difference between the MTLE-HS patients and controls according to genotype and allele frequencies of IL-1 $\beta-511$.

Levels of secreted IL-1 $\beta$ from the cultured lymphocytes incubated either with or without LPS were measured at three different time frames during the culture period (basal, $4 \mathrm{~h}$ and $24 \mathrm{~h}$ ). However, no statistically significant difference was observed between the groups (Table 3). Since IL-1 $\beta-511$ T allele has been suggested to be associated with increased in vitro production of IL- $1 \beta$ and that IL- $1 \beta$ is involved in HS pathogenesis, ${ }^{13,16}$ we also analyzed the IL-1 $\beta$ secretion between the patients and control individuals who carry the T allele at position -511 of the IL-1 $\beta$ gene. However, although spontaneous secretion levels of IL-1 $\beta$ were higher in MTLE-HS patients, there was no significant difference between the groups (Figure 1). In addition, despite the fact that both spontaneous and stimulated secretion levels of IL-1 $\beta$ were higher in MTLE-HS patients who carry the $\mathrm{T}$ allele with respect to those patients who do not, the difference was not statistically significant (Figure 2).

Table 1. Clinical characteristics of mesial temporal lobe epilepsy with hippocampal sclerosis patients and controls.

\begin{tabular}{|c|c|c|c|}
\hline & $\begin{array}{l}\text { MTLE-HS patients } \\
\qquad(\mathrm{n}=30)\end{array}$ & $\begin{array}{l}\text { Controls } \\
(n=32)\end{array}$ & $\mathbf{P}$ \\
\hline Age $($ mean \pm SD) & $29.3 \pm 6.7$ & $30.1 \pm 4.8$ & $>0.05$ \\
\hline Male/female, n. & $16 / 14$ & $10 / 22$ & $>0.05$ \\
\hline History of febrile seizures, n. (\%) & $23(76.7)$ & & \\
\hline Family history of epilepsy, n. (\%) & $6(20)$ & & \\
\hline Age at onset of seizures (year) (mean \pm SD) & $9.1 \pm 5.5$ & & \\
\hline Silent period time (year) $($ mean \pm SD) & $1.3 \pm 0.3$ & & \\
\hline Surgery, n. & $20(66.7 \%)$ & & \\
\hline Post-op follow up time (months) (mean \pm SD) & $19.4 \pm 4.7$ & & \\
\hline Post-op seizure-free time (months) (mean \pm SD) & $15.0 \pm 9.4$ & & \\
\hline
\end{tabular}

MTLE-HS, mesial temporal lobe epilepsy with hippocampal sclerosis; SD, standard deviation.

Table 2. Genotype and allele frequencies of interleukin $1 \beta-511$ in patients and in controls.

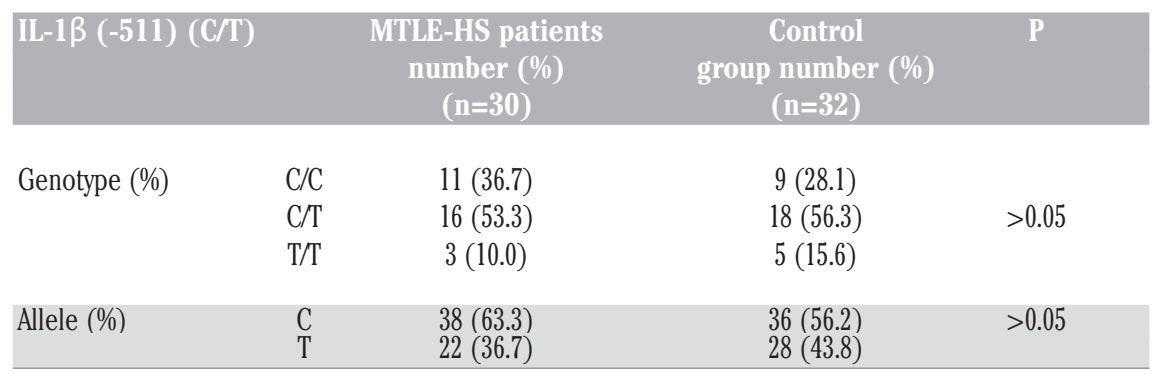

MTLE-HS, mesial temporal lobe epilepsy with hippocampal sclerosis. 


\section{Discussion and Conclusions}

In this study, we found that neither the IL$1 \beta-511 \mathrm{C} / \mathrm{T}$ polymorphism nor the secreted IL$1 \beta$ from the cultured lymphocytes were associated with MTLE-HS in a group of Turkish patients. In our study, the average age of onset of seizures and gender were similar to those presented in other studies.10,13 0 n the other hand, the incidence of history of febrile seizures was found to be $76.7 \%$, which was higher than the values mentioned in several previous reports. $8,17,18$

Cytokine proteins have both pro-inflammatory and anti-inflammatory forms. Among proinflammatory cytokines, IL-1 $\beta$ is one of the key modulators involved in host response to infection. Three biallelic polymorphisms in IL-1 $\beta$, all of which result from $\mathrm{C}$ to $\mathrm{T}$ transitions at positions $-511,-31$ or +3954 from the transcriptional start site, have been most frequently evaluated for their association with diverse conditions besides epilepsy. ${ }^{15,19}$ Chen et al. ${ }^{14}$ demonstrated that the IL-1 $\beta-511 \mathrm{~T}$ allele strongly enhanced the transcription of the IL$1 \beta$ gene in the context of the IL- $1 \beta-31 \mathrm{C}$ allele. IL-1 $\beta-511 \mathrm{~T}$ single nucleotide polymorphism has been thought to be associated with MTLEHS and febrile seizures. ${ }^{8,13,16}$ However, these findings have not been supported by other studies. ${ }^{9,10-12,18}$ Ozkara et al.12 previously showed no association between IL-1 $\beta$ gene polymorphism and TLE with HS in Turkish ancestry in a larger group. This difference in polymorphism frequency has been based on ethnic background. Recently, a meta-analysis and a review was published by Kauffman et al. ${ }^{19}$ demonstrating a modest association between the IL-1 $\beta-511 \mathrm{~T}$ polymorphism and TLE with HS. In the current study, we did not find any significant difference between MTLEHS patients and control group with respect to the genotype and allele frequencies of IL-1 $\beta$ 511 (Table 2). In this study, the frequency of $\mathrm{T} / \mathrm{T}$ genotype was found to be $15.6 \%$ whereas, it was reported to be $18 \%$ and $20.5 \%$ in European and Japanese populations, respectively. 8,20

During the acute phases of status epilepticus, upregulation of IL-1 $\beta$ occurred in activated microglia and astrocytes and sustained inflammation was only evident in astrocytes during epileptogenesis. In chronic epileptic tissue, IL-1 $\beta$ was still expressed by astrocytes, and it resumed in microglia when rats displayed a high frequency of spontaneous seizures. These findings demonstrated that IL$1 \beta$ is chronically over-expressed in astrocytes after status epilepticus, and IL-1 $\beta$ expression in microglia is related to ongoing and severe epileptic activity. 5 Together with IL- $1 \beta$, TNF- $\alpha$ and IL-6 levels increase rapidly after the induction of seizures, then decline to basal levels within 48-72 h of the onset of seizures. But IL-
$1 \beta$ is still up-regulated in the brain 60 days after status epilepticus in rats with spontaneous seizures.3,5 The recent data suggested that lipopolysaccharide mimics the actions of an endogenously released protein called high mobility group box 1 that interacts with Tolllike receptor 4 to promote seizures. IL-1 $\beta$ and high mobility group box 1 activate pathophysiological cascade of inflammatory events in epilepsy through binding to IL-1R1 and Tolllike receptor 4 , respectively. ${ }^{21}$

Besides these experimental studies, some clinical studies have measured IL- $1 \beta$ secretion from the lymphocytes and serum in febrile

Table 3. Spontaneous and stimulated levels of IL-1 $\beta$ in patients and in controls $(\mathrm{pg} / \mathrm{mL})$.

\begin{tabular}{|c|c|c|c|c|}
\hline & Group & $\begin{array}{c}\text { Number } \\
(\text { mean } \pm S D)\end{array}$ & IL-1 $\beta$ levels & $P$ \\
\hline $4 \mathrm{~h}$ & $\begin{array}{l}\text { Patient } \\
\text { Control }\end{array}$ & $\begin{array}{l}30 \\
32\end{array}$ & $\begin{array}{l}130.5 \pm 30.8 \\
100.5 \pm 33.0\end{array}$ & $>0.05$ \\
\hline $4 \mathrm{~h}$ (stimulated) & $\begin{array}{l}\text { Patient } \\
\text { Control }\end{array}$ & $\begin{array}{l}30 \\
32\end{array}$ & $\begin{array}{l}387.5 \pm 89.1 \\
556.0 \pm 81.2\end{array}$ & $>0.05$ \\
\hline $24 \mathrm{~h}$ & $\begin{array}{l}\text { Patient } \\
\text { Control }\end{array}$ & $\begin{array}{l}30 \\
32\end{array}$ & $\begin{array}{l}154.4 \pm 49.5 \\
163.8 \pm 44.5\end{array}$ & $>0.05$ \\
\hline $24 \mathrm{~h}$ (stimulated) & $\begin{array}{l}\text { Patient } \\
\text { Control }\end{array}$ & $\begin{array}{l}30 \\
32\end{array}$ & $\begin{array}{l}429.7 \pm 85.8 \\
561.1 \pm 74.3\end{array}$ & $>0.05$ \\
\hline
\end{tabular}

SD, standard deviation.

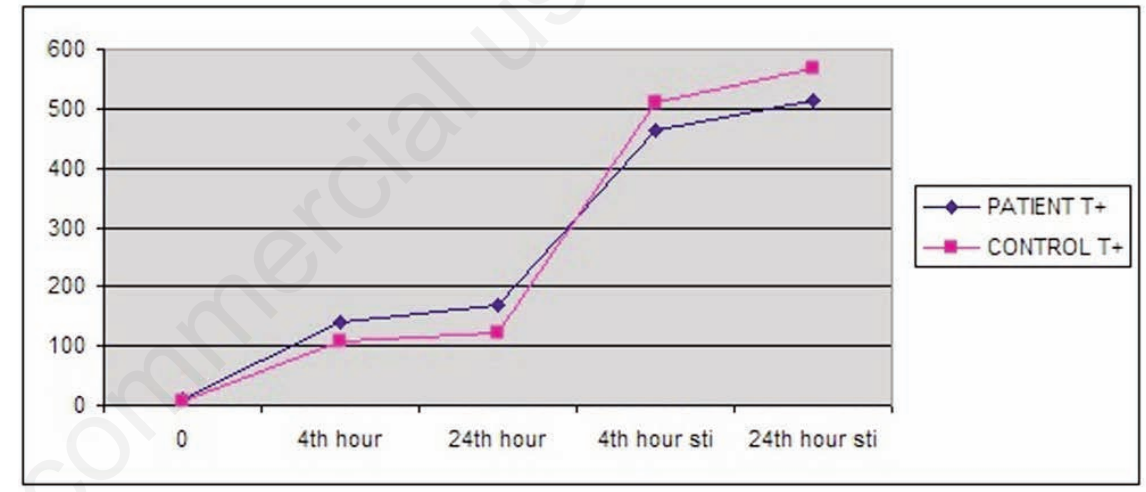

Figure 1. Spontaneous and stimulated levels of IL-1 $\beta$ in patients and in controls, both carry $\mathrm{T}$ allele $(\mathrm{pg} / \mathrm{mL})$. Sti, stimulated; $\mathrm{T}_{+}, \mathrm{T}$ allele carriage.

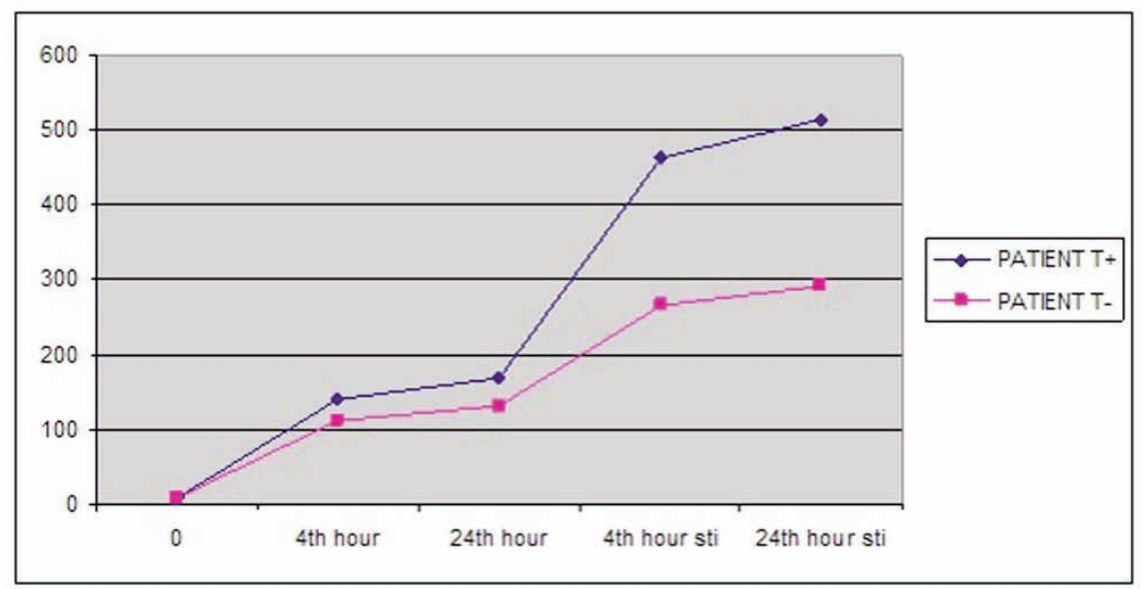

Figure 2. Spontaneous and stimulated levels of IL-1 $\beta$ in patients who carry and who do not carry $T$ allele $(\mathrm{pg} / \mathrm{mL})$. Sti, stimulated; $T_{+}$, patients who carry $T$ allele; $T$-, patients who do not carry $T$ allele. 
seizure and epilepsy patients. Lehtimaki et $a l^{22}$ showed increased plasma levels of IL-6 and levels of IL-1 $\beta$ unchanged after seizures in chronic localization-related epilepsy patients. Similarly, Haspolat et al.23 found no difference between febrile seizure patients and controls with respect to serum IL-1 $\beta$ levels. Liimatainen et al. ${ }^{24}$ reported increased serum levels of IL- 6 in TLE that supported chronic overproduction of cytokines in refractory focal epilepsy. On the other hand, measurement of the secreted IL-1 $\beta$ levels from stimulated lymphocytes can differ from serum levels. Matsuo et al. ${ }^{25}$ demonstrated that IL- $1 \beta$ secretion from the lymphocytes was significantly higher in febrile seizure patients. In another study (Haspolat, unpublished data, 2008), significantly increased levels of IL-1 $\beta$ from LPS-stimulated mononuclear cells at $24 \mathrm{~h}$ were observed in complicated febrile seizure patients compared to simple ones. Although these findings suggest that the increased levels of IL-1 $\beta$ in MTLE-HS patients may lead to HS and explain epileptogenesis and ictogenesis, in this study we were not able to detect any statistically significant differences in secreted IL-1 $\beta$ levels from cultured lymphocytes between the patient and control groups. In addition, comparison of IL-1 $\beta$ levels secreted from lymphocytes obtained from individuals carrying a $\mathrm{T}$ allele at the -511 position of the IL-1 $\beta$ gene to those obtained from individuals who do not carry the $\mathrm{T}$ allele did not reveal any significant difference either. Interestingly, however, the spontaneous and stimulated levels of IL-1 $\beta$ secretion were higher in MTLE-HS patients carrying the $\mathrm{T}$ allele with respect to the patients who do not. The relatively small number of patients and controls could explain the reason why a statistically significant difference was not observed in this study. In addition, it should be kept in mind that promoter regulation is a complex mechanism involving a large variety of transcription factors acting together. Thus, besides (-511) polymorphism, a combination of different haplotypes and many other transcription factors binding to different sites should impinge on the transcriptional activity.

In conclusion, in experimental studies, activation of cytokines has been observed especially in areas of onset of seizures and spreading of discharge. ${ }^{3,7}$ In clinical studies, cytokine levels in peripheral blood seem to reflect the central nervous system's production of cytokines, but these are not always correlat-

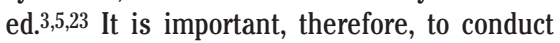
further studies with larger cohorts and evaluation of locally (in situ, in the hippocampal neurons and glial cells) produced IL-1 $\beta$ levels to reveal the possible role of IL-1 $\beta$ in the pathogenesis of HS.

\section{References}

1. Luby M, Spencer DD, Kim JM, et al. Hippocampal MRI volumetrics and temporal lobe substrates in medial temporal lobe epilepsy. Magn Reson Imaging 1995;13:1065-71.

2. Engel $\mathrm{J} \mathrm{Jr}$, Wiebe $\mathrm{S}$, French $\mathrm{J}$, et al. Practice parameter: temporal lobe and localized neocortical resections for epilepsy: report of the Quality Standards Subcommittee of the American Academy of Neurology, in association with the American Epilepsy Society and the American Association of Neurological Surgeons. Neurology 2003;60:538-47.

3. Vezzani A, Granata T. Brain inflammation in epilepsy: experimental and clinical evidence. Epilepsia 2005;46:1724-43.

4. Vezzani A, Baram TZ. New roles for interleukin-1 $\beta$ in the mechanisms of epilepsy. Epilepsy Curr 2007;7:45-50.

5. Ravizza T, Gagliardi B, Noé F, et al. Innate and adaptive immunity during epileptogenesis and spontaneous seizures: evidence from experimental models and human temporal lobe epilepsy. Neurobiol Dis 2008;29:142-60.

6. Ravizza T, Vezzani A. Status epilepticus induces time-dependent neuronal and astrocytic expression of interleukin-1 receptor type I in the rat limbic system. Neuroscience 2006:137:301-8.

7. De Simoni MG, Perego C, Ravizza T, et al. Inflammatory cytokines and related genes are induced in the rat hippocampus by limbic status epilepticus. Eur J Neurosc 2000;12:2623-33.

8. Kanemoto K, Kawasaki J, Miyamoto T, et al. Interleukin (IL)-1 alfa, IL-1 beta, and IL1 receptor antagonist gene polymorphisms in patients with temporal lobe epilepsy. Ann Neurol 2000;47:571-4.

9. Buono RJ, Ferraro TN, O'Connor MJ, et al. Lack of association between an interleukin 1 beta (IL-1beta) gene variation and refractory temporal lobe epilepsy. Epilepsia 2001;42:782-4.

10. Jin L, Jia Y, Zhang B, et al. Association analysis of a polymorphism of interleukin 1 beta (IL-1 beta) gene with temporal lobe epilepsy in a Chinese population. Epilepsia 2003;44:1306-9.

11. Cavalleri GL, Lynch JM, Depondt C, et al. Failure to replicate previously reported genetic associations with sporadic temporal lobe epilepsy: where to from here? Brain 2005;128:1832-40.

12. Ozkara C, Uzan M, Tanriverdi T, et al. Lack of association between IL-1beta/alpha gene polymorphisms and temporal lobe epilepsy with hippocampal sclerosis.
Seizure 2006;15:288-91.

13. Kanemoto K, Kawasaki J, Yuasa S, et al. Increased frequency of interleukin-1beta $511 \mathrm{~T}$ allele in patients with temporal lobe epilepsy, hippocampal sclerosis, and prolonged febrile convulsion. Epilepsia 2003;44:796-9.

14. Chen H, Wilkins LM, Aziz N, et al. Single nucleotide polymorphisms in the human interleukin-1B gene affect transcription according to haplotype context. Hum Mol Genet 2006;15:519-29.

15. Wen AQ, Wang J, Feng K, et al. Effects of haplotypes in the interleukin 1beta promoter on lipopolysaccharide-induced interleukin lbeta expression. Shock 2006;26:25-30.

16. Virta M, Hurme M, Helminen M. Increased frequency of interleukin-1 beta $(-511)$ allele 2 in febrile seizures. Pediatr Neurol 2002;26:192-5.

17. Abou-Khalil B, Andermann E, Andermann F, et al. Temporal lobe epilepsy after prolonged febrile convulsions: excellent outcome after surgical treatment. Epilepsia 1993;34:878-83.

18. Heils A, Haug K, Kunz WS, et al. Interleukin-1beta gene polymorphism and susceptibility to temporal lobe epilepsy with hippocampal sclerosis. Ann Neurol 2000;48:948-50.

19. Kauffman MA, Moron DG, Consalvo D, et al. Association study between interleukin 1 beta gene and epileptic disorders: a HuGe review and meta-analysis. Genet Med 2008;10:83-8.

20. Hulkkonen J, Laippala P, Hurme M. A rare allele combination of the interleukin-1 gene complex is associated with high interleukin-1 beta plasma levels in healthy individuals. Eur Cytokine Netw 2000;11:251-5.

21. Vezzani A, French J, Bartfai T, Baram TZ. The role of inflammation in epilepsy. Nat Rev Neurol 2011;7:31-40.

22. Lehtimäki KA, Keränen T, Palmio J, et al. Increased plasma levels of cytokines after seizures in localization-related epilepsy. Acta Neurol Scand 2007;116:226-30.

23. Haspolat S, Mihci E, Coskun M, et al. Interleukin-1beta, tumor necrosis factoralpha, and nitrite levels in febrile seizures. J Child Neurol 2002;17:749-51.

24. Liimatainen S, Fallah M, Kharazmi E, et al. Interleukin-6 levels are increased in temporal lobe epilepsy but not in extra-temporal lobe epilepsy. J Neurol 2009;256:796802.

25. Matsuo M, Sasaki K, Ichimaru T, et al. Increased IL-1 $\beta$ production from dsRNA stimulated leukocytes in febrile seizures. Pediatr Neurol 2006;35:102-6. 